\title{
Application of Crystalline Silicon Surface Oxidation to Silicon \\ Heterojunction Solar Cells
}

\author{
Takafumi Oikawa ${ }^{1}$, Keisuke Ohdaira ${ }^{1,2, *}$, Koichi Higashimine ${ }^{1,2}$ and Hideki \\ Matsumura ${ }^{1,2}$ \\ ${ }^{1}$ Japan Advanced Institute of Science and Technology \\ 1-1 Asahidai, Nomi, Ishikawa 923-1292, Japan \\ ${ }^{2}$ CREST, Japan Science and Technology Agency \\ 4-1-8 Honcho, Kawaguchi, Saitama 332-0012, Japan \\ Tel: +81-761-51-1563, Fax: +81-761-51-1149 \\ E-mail: ohdaira@jaist.ac.jp
}

\begin{abstract}
We study the effect of ultra-thin oxide $\left(\mathrm{SiO}_{\mathrm{x}}\right)$ layers inserted at the interface of silicon heterojunction (SHJ) solar cells on their open-circuit voltage $\left(\mathrm{V}_{\mathrm{OC}}\right)$. The $\mathrm{SiO}_{\mathrm{x}}$ layers can be easily formed by dipping c-Si into oxidant such as hydrogen peroxide $\left(\mathrm{H}_{2} \mathrm{O}_{2}\right)$ and nitric acid $\left(\mathrm{HNO}_{3}\right)$. We confirm the prevention of the undesirable epitaxial growth of $\mathrm{Si}$ layers during the deposition of a-Si films by the insertion of the ultra-thin $\mathrm{SiO}_{\mathrm{x}}$ layers. The formation of the $\mathrm{SiO}_{x}$ layers by $\mathrm{H}_{2} \mathrm{O}_{2}$ leads to better effective minority carrier lifetime $\left(\tau_{\text {eff }}\right)$ and $\mathrm{V}_{\mathrm{OC}}$ than the case of using $\mathrm{HNO}_{3}$. c-Si with the ultra-thin $\mathrm{SiO}_{\mathrm{x}}$ layers formed by $\mathrm{H}_{2} \mathrm{O}_{2}$ dipping, prior to deposition of a-Si passivation layers, can have high implied $\mathrm{V}_{\text {OC }}$ of up to $\sim 0.714 \mathrm{~V}$.
\end{abstract}

\section{Keywords:}


Heterojunction solar cell, Ultra-thin $\mathrm{SiO}_{\mathrm{x}}$ layer, Cat-CVD, Passivation, Epitaxial growth 


\section{INTRODUCTION}

The demand of solar cells has been growing in the last decade, and for more spread of photovoltaics, further improvement in the conversion efficiency is required [1]. Since crystalline silicon (c-Si) wafer-based solar cells are the most popular structures in the photovoltaic market at present, the enhancement of their conversion efficiency is of great importance [1]. Of a variety of Si wafer-based solar cells, Si heterojunction (SHJ) $\underline{\text { solar cells have recently received much attention [2-6]. The SHJ solar cell is composed }}$ of a c-Si wafer and hydrogenated amorphous Si (a-Si) films, and has a plenty of advantages such as high conversion efficiency accompanied by high open-circuit voltage $\left(\mathrm{V}_{\mathrm{OC}}\right)$ and low manufacturing temperatures. Intrinsic a-Si (i-a-Si) films are utilized for the passivation of crystalline Si (c-Si) surfaces owing to the effect of abundant hydrogen in the a-Si films. The best reported $\mathrm{V}_{\mathrm{OC}}$ is $0.750 \mathrm{~V}$ with an efficiency of $24.7 \%$ for a conventional SHJ structure [2] and $0.740 \mathrm{~V}$ with an efficiency of $25.6 \%$ for a heterojunction back-contact (HBC) structure [3]. The SHJ solar cells have thus been expected to be in the mainstream of next-generation c-Si solar cells.

For high-efficiency SHJ solar cells, i-a-Si passivation layers realizing sufficiently low surface recombination velocity is essential. The i-a-Si passivation films are generally formed by plasma-enhanced chemical vapor deposition (PECVD), in which the suppression of plasma damage onto c-Si surfaces is often problematic. In contrast, catalytic CVD (Cat-CVD), often also referred to as hot-wire CVD, can form i-a-Si passivation films without plasma damage since its gas decomposition mechanism is not based on plasma process but through catalytic cracking on a heated catalyzing wire $[7,8]$. Cat-CVD is thus expected to be superior for the fabrication of SHJ solar cells. It should be noted that the passivation property of a-Si/c-Si interfaces is governed not only by the 
quality of i-a-Si itself and a degree of damage onto c-Si during deposition but also by the presence or the absence of the epitaxial growth of Si $[9,10]$. Silane $\left(\mathrm{SiH}_{4}\right)$ molecules are decomposed to one Si and four $\mathrm{H}$ atoms on a heated catalyzed wire in Cat-CVD [1116], and due to the existence of bare Si radicals, the epitaxial growth of Si is more likely to occur in Cat-CVD [17]. The development of a method to prevent the Si epitaxial growth is thus required particularly for the application of Cat-CVD to the formation of a-Si passivation films. One of the possible approaches is to vanish the periodicity of c$\underline{\text { Si lattice on the surface by forming an amorphous thin film on the c-Si. The formation }}$ of ultra-thin $\mathrm{Si}$ oxide $\left(\mathrm{SiO}_{\mathrm{x}}\right.$ ) layers is a promising candidate for such a thin film since it can be easily formed by the oxidation of a c-Si surface and does not prevent carrier transport if it is sufficiently thin [18-21].

In this study, we have attempted to form ultra-thin $\mathrm{SiO}_{\underline{x}}$ layers on c-Si surfaces for preventing the epitaxial growth during the Cat-CVD of a-Si films by dipping c-Si wafers into hydrogen peroxide $\left(\mathrm{H}_{2} \underline{\mathrm{O}}_{2}\right)$ or nitric acid $\left(\mathrm{HNO}_{3}\right)$. We have also applied the c-Si surface oxidation to the fabrication of SHJ solar cells to confirm the effect of oxidation process against solar cell performance.

\section{EXPERIMENTAL DETAILS}

We used double-side-polished floating-zone (FZ) n-type c-Si wafers which have (100) orientation, a thickness of $290 \mu \mathrm{m}$, a resistivity of $\sim 2 \Omega \mathrm{cm}$, and a bulk lifetime $\left(\tau_{\underline{b}}\right)$ of $>10 \mathrm{~ms}$. We first cleaved c-Si wafers into $2 \mathrm{~cm} \times 2 \mathrm{~cm}$-sized pieces, and native oxide layers on the Si wafers were removed in a 5\% HF solution diluted with deionized water. The wafers were then immediately dipped in $0.5-10$ wt $\% \mathrm{H}_{2} \mathrm{O}_{2}$ or $\mathrm{HNO}_{3}$ for 30 seconds at room temperature to form the ultra-thin $\mathrm{SiO}_{\mathrm{x}}$ layers on c-Si surfaces. $\underline{\mathrm{We}}$ 


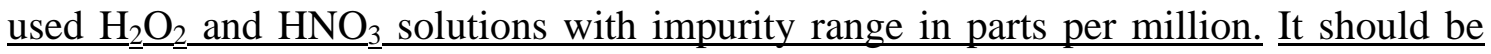
noted that longer dipping in the oxidants does not lead to any different results, which is probably because of low treatment temperature and resulting saturation of oxidation. The thickness of the ultra-thin $\mathrm{SiO}_{x}$ layers evaluated by ellipsometry was $0.8-1.0 \mathrm{~nm}$. Some of the ultra-thin $\mathrm{SiO}_{\mathrm{x}}$ layers formed were characterized by attenuated total reflectance Fourier transform infrared (ATR-FTIR) spectroscopy. We prepared i-a-Si/c$\mathrm{Si} / \mathrm{i}-\mathrm{a}-\mathrm{Si}$ and $\mathrm{i}-\mathrm{a}-\mathrm{Si} / \mathrm{SiO}_{\mathrm{x}} / \mathrm{c}-\mathrm{Si} / \mathrm{SiO}_{\mathrm{X}} / \mathrm{i}-\mathrm{a}-\mathrm{Si}$ structures to confirm the effect of epitaxial growth and passivation quality. In these experiments, a-Si layers were deposited in a Cat-CVD system with changing substrate temperatures. Deposition pressure and $\mathrm{SiH}_{4}$ flow rate were fixed at $1.0 \mathrm{~Pa}$ and $10 \mathrm{sccm}$, respectively. Deposition duration was also fixed at 30 second, which resulted in the a-Si thickness of 8-9 $\mathrm{nm}$. We used a tungsten wire as catalyzer heated at $1800^{\circ} \mathrm{C}$ for all the experiments. After the deposition of a-Si films, the samples were annealed at $200{ }^{\circ} \mathrm{C}$ for $30 \mathrm{~min}$ in air in order to improve the quality of a-Si/c-Si and a-Si/SiO ${ }_{x} / \mathrm{c}-\mathrm{Si}$ interfaces. The emergence of epitaxial growth was evaluated by spectroscopic ellipsometry and cross-sectional transmission electron microscopy (TEM). The quality of the a-Si/c-Si interfaces was characterized from the effective minority carrier lifetime $\left(\tau_{\text {eff }}\right)$ measured by the microwave photoconductivity decay $(\mu-P C D)$ method.

For SHJ solar cell fabrication, n-a-Si/i-a-Si films were deposited on one side of c-Si after the formation of ultra-thin $\mathrm{SiO}_{\mathrm{x}}$ layers and p-a-Si/i-a-Si films were then deposited on the other side. We used $\mathrm{PH}_{3}$ and $\mathrm{B}_{2} \mathrm{H}_{6}$ gases diluted with helium to $2.25 \%$ to form the doped a-Si layers. 80-nm-thick indium tin oxide (ITO) films were sputtered on the both sides of the samples at a substrate temperature of $100^{\circ} \mathrm{C}$. We then formed combshaped Ag electrodes formed by screen printing and successive annealing at $200{ }^{\circ} \mathrm{C}$. 
The deposition condition of the a-Si films is summarized in Table I. Note that the values in the parentheses represent those used for SHJ solar cell fabrication. We also prepared solar cells without the oxidation of c-Si surfaces for comparison. We measured $\tau_{\text {eff }}$ and implied $\mathrm{V}_{\mathrm{OC}}$ by $\mu$-PCD and quasi-steady-state photoconductivity (QSSPC), respectively, before the formation of ITO films and Ag electrodes. We characterized the solar cell performance by current density-voltage $(\mathrm{J}-\mathrm{V})$ measurement under 1-sun (AM1.5, 100 $\mathrm{mW} / \mathrm{cm}^{2}$ ) illumination.

\section{RESULTS AND DISCUSSION}

\subsection{Prevention of epitaxial growth}

Figure 1 shows the thickness of $\mathrm{i}-\mathrm{a}-\mathrm{Si}$ films on c-Si wafers with and without oxidation under various oxidant concentrations up to $10 \mathrm{wt} \%$ for $\mathrm{H}_{2} \mathrm{O}_{2}$ and $30 \mathrm{wt} \%$ for $\mathrm{HNO}_{3}$ as a function of substrate temperature during the deposition of i-a-Si films. The thickness of i-a-Si films on c-Si without ultra-thin $\mathrm{SiO}_{\mathrm{x}}$ layers decreases significantly with increase in substrate temperatures. This is probably because deposited Si layers are epitaxially grown in some parts, and such epitaxially grown c-Si layers with same optical properties as c-Si wafers cannot be distinguished by spectroscopic ellipsometry. Reduction in a-Si film thickness thus indicates the emergence of epitaxial growth. On the contrary, reduction in i-a-Si film thickness is less significant in the case of the samples with oxidation. This tendency is more remarkable for the structures treated in higher oxidant concentration. These results clearly indicate that the ultra-thin $\mathrm{SiO}_{\mathrm{x}}$ layers formed on c-Si can effectively prevent the epitaxial growth.

The results above indicate that the epitaxial growth can be suppressed both by $\mathrm{H}_{2} \mathrm{O}_{2}$ and $\mathrm{HNO}_{3}$ treatment. One can also see in Fig. 1 that epitaxial growth is adequately 
prevented at a deposition temperature of around $180{ }^{\circ} \mathrm{C}$ even at a $\mathrm{H}_{2} \underline{\mathrm{O}}_{2} \underline{\text { concentration of }}$ as low as 0.5 wt $\%$ in $\mathrm{H}_{2} \underline{\mathrm{O}}_{2}$, while the effective suppression of epitaxial growth is realized only at much higher $\mathrm{HNO}_{3}$ concentration of about $30 \mathrm{wt} \%$. The reason for this difference may originate from different oxidation mechanism depending on oxidant, which will be discussed in section 3.4.

According to these results, we have clearly confirmed the effectiveness of inserting thin $\mathrm{SiO}_{\mathrm{x}}$ layers for the prevention of epitaxial growth. In the case of high oxidant solution concentration, under which epitaxial growth is sufficiently suppressed, it is thus possible to deposit a-Si passivation layers at higher temperatures. This would leads to the utilization of a-Si films with better film quality.

We also confirm the prevention of the epitaxial growth by forming ultra-thin $\mathrm{SiO}_{\mathrm{x}}$ layers on c-Si by TEM observation. Figures 2(a) and (b) show the cross-sectional TEM images of a-Si/c-Si and a-Si/SiO $x$ /c-Si structures. Note that these TEM images were observed in the SHJ structures, and deposited Si exists in the region of 8-9 nm from c-Si interface. In the case of the sample without oxidation, epitaxially-grown c-Si is definitely seen at some places. On the other hand, the epitaxial growth is almost completely prevented in the sample with $\mathrm{H}_{2} \underline{\mathrm{O}}_{2} \underline{2}_{2}$ oxidation. This result clearly demonstrates the benefit of the $\mathrm{SiO}_{\mathrm{x}}$ layer insertion to obtain high quality a-Si/c-Si interfaces.

\subsection{Oxidant concentration dependence of minority carrier lifetime}

Figures 3 shows $\tau_{\text {eff }}$ of $\mathrm{i}-\mathrm{a}-\mathrm{Si} / \mathrm{c}-\mathrm{Si} / \mathrm{i}-\mathrm{a}-\mathrm{Si}$ structures with c-Si oxidized in $\mathrm{H}_{2} \mathrm{O}_{2}$ or $\mathrm{HNO}_{3}$ with up to $10 \mathrm{wt} \%$ oxidant concentrations. i-a-Si films on the structures were deposited at $160{ }^{\circ} \mathrm{C}$. The samples without $\mathrm{SiO}_{\mathrm{x}}$ layers show low $\tau_{\text {eff }}$ of less than $50 \mu \mathrm{s}$. 
According to the results shown in Figure 1, the epitaxial growth of defective c-Si occurs, and the a-Si/c-Si interface quality is thus deteriorated. On the contrary, $\tau_{\text {eff }}$ is improved in the samples with $\mathrm{SiO}_{\mathrm{x}}$ layers. This result indicates that the formation of ultra-thin $\mathrm{SiO}_{\mathrm{x}}$ layers on c-Si surfaces is effective in improving the quality of a-Si/c-Si heterojunction interfaces. The $\mathrm{H}_{2} \mathrm{O}_{2}$-oxidized samples show the maximum $\tau_{\text {eff }}$ of $600 \mu \mathrm{s}$ at an oxidant concentration of 3-5 wt $\% . \mathrm{H}_{2} \mathrm{O}_{2}$ with a concentration of more than $5 \mathrm{wt} \%$ may induce surface damage due to excessive oxidation and resulting reduction in $\tau_{\text {eff }}$. Compared to the $\mathrm{H}_{2} \mathrm{O}_{2}$-oxidized samples, the dependence of $\tau_{\text {eff }}$ on $\mathrm{HNO}_{3}$ concentration is not clear. Furthermore, the maximum $\tau_{\text {eff }}$ of $\mathrm{H}_{2} \mathrm{O}_{2}$-oxidized samples is much higher than those of $\mathrm{HNO}_{3}$-oxidized samples. These may be not only due to the degree of epitaxial growth but also due to the difference of the quality of $\mathrm{SiO}_{\mathrm{x}}$ layers themselves.

\subsection{J-V characteristics}

The relationship between the oxidant concentration and $\mathrm{V}_{\mathrm{OC}}$ or fill factor (FF) of the SHJ solar cells with ultra-thin $\mathrm{SiO}_{\mathrm{x}}$ layers formed in $\mathrm{H}_{2} \mathrm{O}_{2}$ or $\mathrm{HNO}_{3}$ are shown in Figure 4. The SHJ cells with ultra-thin $\mathrm{SiO}_{\mathrm{x}}$ layers show better $\mathrm{V}_{\mathrm{OC}}$ compared to the cells without oxidation. $\mathrm{V}_{\mathrm{OC}}$ is nearly independent of oxidant concentration at more than 0.5 wt\% in both oxidant solutions. This result is unlikely the i-a-Si passivation experiments, in which clear dependence of $\tau_{\text {eff }}$ on oxidant concentration is seen. This may be due to the difference of sample structure. In the SHJ cells, n- and p-a-Si films are additionally deposited, and these doped a-Si films may affect the quality of a-Si/c-Si interfaces. Focusing on the absolute values of $\mathrm{V}_{\mathrm{OC}}$, the $\mathrm{SHJ}$ cell with $\mathrm{SiO}_{\mathrm{x}}$ layers formed by $\mathrm{H}_{2} \mathrm{O}_{2}$ has higher $\mathrm{V}_{\mathrm{OC}}$ than that with $\mathrm{HNO}_{3}$-oxidized layers. This fact is consistent with 
previous results demonstrating more suppressed epitaxial growth and higher $\tau_{\text {eff }}$ shown in Figures 1-3.

On the other hand, FF shows a different tendency against oxidant concentration depending on oxidant solutions. The SHJ cells with $\mathrm{H}_{2} \mathrm{O}_{2}$ treatment has lower FF than the cell without oxidation treatment, and FF decreases to $\sim 0.4$ with increasing $\mathrm{H}_{2} \mathrm{O}_{2}$ concentration. The SHJ cells with $\mathrm{HNO}_{3}$ treatment have a constant FF regardless of the oxidant concentration. FF is generally affected by series or shunt resistances. The SHJ solar cells fabricated in this study have sufficiently large shunt resistance, which was confirmed through pseudo FF (pFF) obtained by Suns- $\mathrm{V}_{\mathrm{OC}}$ measurement. A possible impact on the FF is thus series resistance. In the SHJ cells with $\mathrm{H}_{2} \mathrm{O}_{2}$ treatment, $\mathrm{SiO}_{x}$ layers themselves may act as series resistance since FF decreases with increase in oxidant concentration. In particular, increase in the thickness and density of $\mathrm{SiO}_{\mathrm{x}}$ layers by high concentration treatment can be a significant impact on series resistance and FF. On the contrary, the FF of the SHJ cells with $\mathrm{HNO}_{3}$ oxidation has no dependence on oxidant concentration. This may be because the thickness of $\mathrm{SiO}_{\mathrm{x}}$ layer formed by $\mathrm{HNO}_{3}$ treatment does not increase significantly even higher $\mathrm{HNO}_{3}$ concentration [21].

The previous results show that $\mathrm{H}_{2} \mathrm{O}_{2}$ treatment leads to better a-Si/c-Si interface quality and cell performance. Figure 5 and Table II show J-V characteristics of SHJ solar cells with and without $\mathrm{H}_{2} \mathrm{O}_{2}$ treatment. Note that the deposition conditions of a-Si films were slightly changed to obtain better solar cell performance, which are shown in parentheses in Table I. We can clearly see the impact of $\mathrm{SiO}_{\mathrm{x}}$ layer insertion on $\tau_{\text {eff }}$ and $\mathrm{V}_{\text {OC. }}$ In particular, implied $\mathrm{V}_{\mathrm{OC}}$ reaches $0.714 \mathrm{~V}$, which is much larger than the implied $\mathrm{V}_{\mathrm{OC}}$ of the sample without $\mathrm{H}_{2} \mathrm{O}_{2}$ treatment of $0.591 \mathrm{~V}$. It should be noted that $\mathrm{V}_{\mathrm{OC}}$ obtained by J-V measurement is smaller than implied $\mathrm{V}_{\mathrm{OC}}$ for both SHJ cells. This may 
be due to plasma damage onto a-Si/c-Si interfaces during ITO sputtering [22]. Although the FFs of J-V curves are insufficient at present due to relatively high series resistance, this can be partly improved by optimizing the sheet resistance of ITO and the thickness of a-Si layers.

\subsection{ATR-FTIR measurement of oxidized Si (100)}

In order to understand the different tendency of passivation quality and cell characteristics depending on the type of oxidant solution, we have attempted to evaluate the characteristics of ultra-thin $\mathrm{SiO}_{\mathrm{x}}$ film using ATR-FTIR measurement. Figure 6 shows the FTIR spectra of $\mathrm{Si}$ (100) samples treated in (a) $\mathrm{H}_{2} \mathrm{O}_{2}$ and (b) $\mathrm{HNO}_{3}$. One can see two characteristic peaks at $2110 \mathrm{~cm}^{-1}$ and $2141 \mathrm{~cm}^{-1}$, corresponding to $\mathrm{SiH}_{2}$ and $\mathrm{SiH}_{3}$ stretching vibration band, respectively [23,24], for the samples with oxidation in low concentration oxidant. These peaks derive from hydrogen-terminated Si surfaces formed by $\mathrm{HF}$ dipping. With increasing $\mathrm{H}_{2} \mathrm{O}_{2}$ concentration, $\mathrm{SiH}_{2}$ and $\mathrm{SiH}_{3}$ vibration bands disappear, while the intensity of a peak at $2243 \mathrm{~cm}^{-1}$ increases. This peak originates from $\mathrm{SiO}_{3} \mathrm{H}$ bonds which can be created if all the back bond $\mathrm{Si}$ atoms are replaced to $\mathrm{O}$ by oxidation [25]. The emergence of the $\mathrm{SiO}_{3} \mathrm{H}$ peak is a clear evidence of the oxidation of $\mathrm{Si}$. On the other hand, In spite of reduction in $\mathrm{SiH}_{2}$ and $\mathrm{SiH}_{3}$ peaks, a $\mathrm{SiO}_{3} \mathrm{H}$ peak does not appear after $\mathrm{HNO}_{3}$ oxidation even at high $\mathrm{HNO}_{3}$ concentration. This suggests that oxygen atoms in $\mathrm{HNO}_{3}$ solution hardly react with the back bond $\mathrm{Si}$ atoms. $\mathrm{SiO}_{3} \mathrm{H}$ is a dominant structure on a $\mathrm{Si}(100)$ surface oxidized in $\mathrm{H}_{2} \mathrm{O}_{2}$ [26]. When the back bonds are oxidized, strain due to the interfacial volume expansion occurs [27]. This may behave as an electrical resistance, which could explain the decrease in FF of SHJ cells with increase in $\mathrm{H}_{2} \mathrm{O}_{2}$ concentration. In the case of $\mathrm{HNO}_{3}$-oxidized samples, 
according to Gondek et al., compared with the oxidation of H-terminated Si surfaces by $\mathrm{H}_{2} \mathrm{O}_{2}, \mathrm{HNO}_{3}$-oxidized samples show higher $\mathrm{SiOH}$ species $\left(3000-3600 \mathrm{~cm}^{-1}\right)$ than $\mathrm{H}_{2} \mathrm{O}_{2}$ oxidized samples [28], although it was not clearly observed in this measurement. This indicates more adsorption of $\mathrm{H}_{2} \mathrm{O}$ on $\mathrm{HNO}_{3}$-treated c-Si surfaces [29]. Oxidation by $\mathrm{HNO}_{3}$ is generally performed at higher $\mathrm{HNO}_{3}$ concentrations and at high temperatures [20,21]. Oxidation in $\mathrm{HNO}_{3}$ at room temperature performed in this study may be insufficient for effective Si surface oxidation. We should also discuss the suppression of epitaxial growth by $\mathrm{HNO}_{3}$ treatment even without the formation of $\mathrm{SiO}_{\mathrm{x}}$ layers. As mentioned above, a number of $\mathrm{OH}$ bonds are adhered on a Si surface after $\mathrm{HNO}_{3}$ treatment. This might contribute to the suppression of epitaxial growth to some extent, which is less effective for the prevention of epitaxial growth than the case of $\mathrm{H}_{2} \mathrm{O}_{2}$ oxidation. The difference in the passivation quality may thus be related to the presence of $\mathrm{SiO}_{3} \mathrm{H}$ bonds.

\section{CONCLUSION}

The formation of ultra-thin $\mathrm{SiO}_{\mathrm{x}}$ layers by dipping in oxidant solution is applied to SHJ solar cell process. The introduction of ultra-thin $\mathrm{SiO}_{\mathrm{x}}$ layers between a-Si/c-Si interfaces results in improvement in $\tau_{\text {eff }}$ and $V_{\text {OC }}$ due to the prevention of the epitaxial growth. $\tau_{\text {eff }}$ significantly improves when we apply $\mathrm{H}_{2} \mathrm{O}_{2}$ treatment with a concentration of 3-5 wt\%. A SHJ solar cell with 4 wt $\% \mathrm{H}_{2} \mathrm{O}_{2}$ treatments shows $\mathrm{V}_{\mathrm{OC}}$ and implied $\mathrm{V}_{\mathrm{OC}}$ up to $0.683 \mathrm{~V}$ and $0.714 \mathrm{~V}$, respectively. The results obtained have clearly demonstrated the effectiveness of ultra-thin $\mathrm{SiO}_{\mathrm{x}}$ layers formed by $\mathrm{H}_{2} \mathrm{O}_{2}$ dipping for improvement in the performance of SHJ solar cells. 


\section{ACKNOWLEDGMENT}

The authors would like to thank Prof. Usami and Dr. Takahashi of Nagoya University for ATR FT-IR measurement. This work was supported by JST CREST program. 


\section{REFERENCES}

[1] C. Zheng, D. M. Kammen, An innovation-focused roadmap for a sustainable global photovoltaic industry, Energy Policy 67 (2014) 159.

[2] M. Taguchi, A. Yano, S. Tohoda, K. Matsuyama, Y. Nakamura, T. Nishiwaki, K. Fujita, E. Maruyama, 24.7\% Record efficiency HIT solar cell on thin silicon wafer, IEEE J. Photovoltaics 4 (2014) 96.

[3] K. Masuko, M. Shigematsu, T. Hashiguchi, D. Fujishima, M. Kai, N. Yoshimura, T. Yamaguchi, Y. Ichihashi, T. Mishima, N. Matsubara, T. Yamanishi, T. Takahama, M. Taguchi, E. Maruyama, S. Okamoto, Achievement of more than 25\% conversion efficiency with crystalline silicon heterojunction solar cell, IEEE J. Photovoltaics 4 (2014) 1433.

[4] J. Nakamura, N. Asano, T. Hieda, C. Okamoto, H. Katayama, K. Nakamura, Development of heterojunction back contact Si solar cells, IEEE J. Photovoltaics 4, 1491 (2014).

[5] S. De Wolf, A. Descoeudres, Z. C. Holman, C. Ballif, High-efficiency silicon heterojunction solar cells: a review, Green 2 (2012) 7.

[6] J. L. Hernández, D. Adachi, D. Schroos, N. Valckx, N. Menou, T. Uto, M. Hino, M. Kanematsu, H. Kawasaki, R. Mishima, K. Nakano, H. Uzu, T. Terashita, K. Yoshikawa, T. Kuchiyama, M. Hiraishi, N. Nakanishi, M. Yoshimi, and K. Yamamoto, High efficiency copper electroplated heterojunction solar cells and modules - the path towards 25\% cell efficiency, Proc. 28th European Photovoltaic Solar Energy Conf., 2013, p. 741. 
[7] K. Koyama, K. Ohdaira, H. Matsumura, Extremely low surface recombination velocities on crystalline silicon wafers realized by catalytic chemical vapor deposited sinx/a-si stacked passivation layers, Appl. Phys. Lett. 97 (2010) 082108.

[8] S. Tsuzaki, K. Ohdaira, T. Oikawa, K. Koyama, H. Matsumura, Improvement in passivation quality and open-circuit voltage in silicon heterojunction solar cells by the catalytic doping of phosphorus atoms, Jpn. J. Appl. Phys. 54 (2015) 072301.

[9] T. H. Wang, E. Iwaniczko, M. R. Page, D. H. Levi, Y. Yan, H. M. Branz, Q. Wang, Effect of emitter deposition temperature on surface passivation in hot-wire chemical vapor deposited silicon heterojunction solar cells, Thin Solid Films 501 (2006) 284.

[10] S. De. Wolf, M. Kondo, Abruptness of a-Si:H/c-Si interface revealed by carrier lifetime measurements, Appl. Phys. Lett. 90 (2007) 042111.

[11] Y. Nozaki, K. Kongo, T. Miyazaki, M. Kitazoe, K. Horii, H. Umemoto, A. Masuda, H. Matsumura, Identification of $\mathrm{Si}$ and $\mathrm{SiH}$ in catalytic chemical vapor deposition of $\mathrm{SiH}_{4}$ by laser induced fluorescence spectroscopy, J. Appl. Phys. 88 (2000) 5437.

[12] Y. Nozaki, M. Kitazoe, K. Horii, H. Umemoto, A. Masuda, H. Matsumura, Identification and gas phase kinetics of radical species in Cat-CVD processes of $\mathrm{SiH}_{4}$, Thin Solid Films 395 (2001) 47.

[13] S.Tange, K. Inoue, K. Tonokura, M. Koshi, Catalytic decomposition of $\mathrm{SiH}_{4}$ on a hot filament, Thin Solid Films 395 (2001) 42.

[14] H. L. Duan, G. A. Zaharias, S. F. Bent, The effect of filament temperature on the gaseous radicals in the hot wire decomposition of silane, Thin Solid Films 395 (2001) 36. 
[15] H. L. Duan, G. A. Zaharias, S. F. Bent, Probing radicals in hot wire decomposition of silane using single photon ionization, Appl. Phys. Lett. 78 (2001) 1784.

[16] K. Tonokura, K. Inoue, M. Koshi, Chemical kinetics for film growth in silicon HWCVD, J. Non-Cryst. Solids 299-302 (2002) 25.

[17] Q. Wang, M. Page, Y. Ai, W. Nemeth, L. Roybal, H. C. Yuan, Hydrogenated amorphous Si deposition for high efficiency a-Si/c-Si heterojunction solar cells, Proc. 39th IEEE Photovoltaic Specialists Conference, 2013, p. 188.

[18] Y. Lee, W. Oh, V. A. Dao, S. Q. Hussain, J. Yi, Ultrathin oxide passivation layer by rapid thermal oxidation for the silicon heterojunction solar cell applications, Int. J. Photoenergy 2012 (2012) 753456.

[19] U. Neuwald, A. Feltz, U. Memmert, R. J. Behm, Chemical oxidation of hydrogen passivated $\mathrm{Si}$ (111) surfaces in $\mathrm{H}_{2} \mathrm{O}_{2}$, J. Appl. Phys. 78 (1995) 4131.

[20] W. B. Kim, T. Matsumoto, H. Kobayashi, Ultrathin $\mathrm{SiO}_{2}$ layer with an extremely low leakage current density formed in high concentration nitric acid, J. Appl. Phys. 105 (2009) 103709.

[21] H. Kobayashi, K. Imamura, W. B. Kim, S. S. Im, Asuha, Nitric acid oxidation of Si (NAOS) method for low temperature fabrication of $\mathrm{SiO}_{2} / \mathrm{Si}$ and $\mathrm{SiO}_{2} / \mathrm{SiC}$ structures, Appl. Surf. Sci. 256 (2010) 5744.

[22] B. Demaurex, S. De Wolf, A. Descoeudres, Z. C. Holman, C. Ballif, Damage at hydrogenated amorphous/crystalline silicon interfaces by indium tin oxide overlayer sputtering, Appl. Phys. Lett. 101 (2012) 171604.

[23] Y. J. Chabal, A. L. Harris, K. Raghavachari, J. C. Tully, Infrared spectroscopy of H-terminated silicon surfaces, Int. J. Mod. Phys. B 7 (1993) 1031

[24]Z. H. Wang, T. Urisu, H. Watanabe, K. Ooi, G. R. Rao, S. Nanbu, J. Maki, M. 
Aoyagi, Assignment of surface IR absorption spectra observed in the oxidation reactions: $2 \mathrm{H}+\mathrm{H}_{2} \mathrm{O} / \mathrm{Si}(100)$ and $\mathrm{H}_{2} \mathrm{O}+\mathrm{H} / \mathrm{Si}$ (100), Surf. Sci. 575 (2005) 330 .

[25]G. Lucovsky, J. Yang, S. S. Chao, J. E. Tyler, W. Czubatyj, Oxygen-bonding environments in glow-discharge-deposited amorphous silicon-hydrogen alloy films, Phys. Rev. B 28 (1983) 3225.

[26] Y. Sugita, S. Watanabe, In situ infrared spectroscopy on the wet chemical oxidation of hydrogen-terminated Si surfaces, Jpn. J. Appl. Phys. 37 (1998) 3272.

[27] D. Sander, H. Ibach, Experimental determination of adsorbate-induced surface stress: oxygen on Si (111) and Si (100), Phys. Rev. B 43 (1991) 4263.

[28] C. Gondek, M. Lippold, I. Röver, K. Bohmhammel, E. Kroke, Etching silicon with $\mathrm{HF}-\mathrm{H}_{2} \mathrm{O}_{2}$-based mixtures: reactivity studies and surface investigations, J. Phys. Chem. C 118 (2014) 2044.

[29] T. Yuden, A. Yoshigoe, Reaction Dynamics of Si (001) oxidation at room temperature induced by supersonic $\mathrm{O}_{2}$ molecular beams, Hyomen Kagaku 23 (2002) 553. 


\section{FIGURE CAPTIONS}

Figure 1 Thickness of a-Si films as a function of substrate temperature during film deposition on c-Si treated in (a) $\mathrm{H}_{2} \mathrm{O}_{2}$ and (b) $\mathrm{HNO}_{3}$ at various concentrations.

Figure 2 Cross-sectional TEM images of (a)a-Si/c-Si and (b) a-Si/SiO ${ }_{x} / c-S i$ stacked structures

Figure $3 \tau_{\text {eff }}$ of c-Si wafers passivated with i-a-Si films as a function of oxidant concentration.

Figure 4 Oxidant concentration dependence of $\mathrm{V}_{\mathrm{OC}}$ and FF of SHJ solar cells treated using (a) $\mathrm{H}_{2} \mathrm{O}_{2}$ or (b) $\mathrm{HNO}_{3}$.

Figure $5 \mathrm{~J}-\mathrm{V}$ characteristics of the SHJ solar cells without and with ultra-thin $\mathrm{SiO}_{\mathrm{x}}$ layers on c-Si formed by dipping in $4.0 \mathrm{wt} \% \mathrm{H}_{2} \mathrm{O}_{2}$.

Figure 6 ATR-FTIR spectra of Si (100) surfaces oxidized for 30 seconds at room temperature in (a) $\mathrm{H}_{2} \mathrm{O}_{2}$ or (b) $\mathrm{HNO}_{3}$ solutions with various concentrations. 

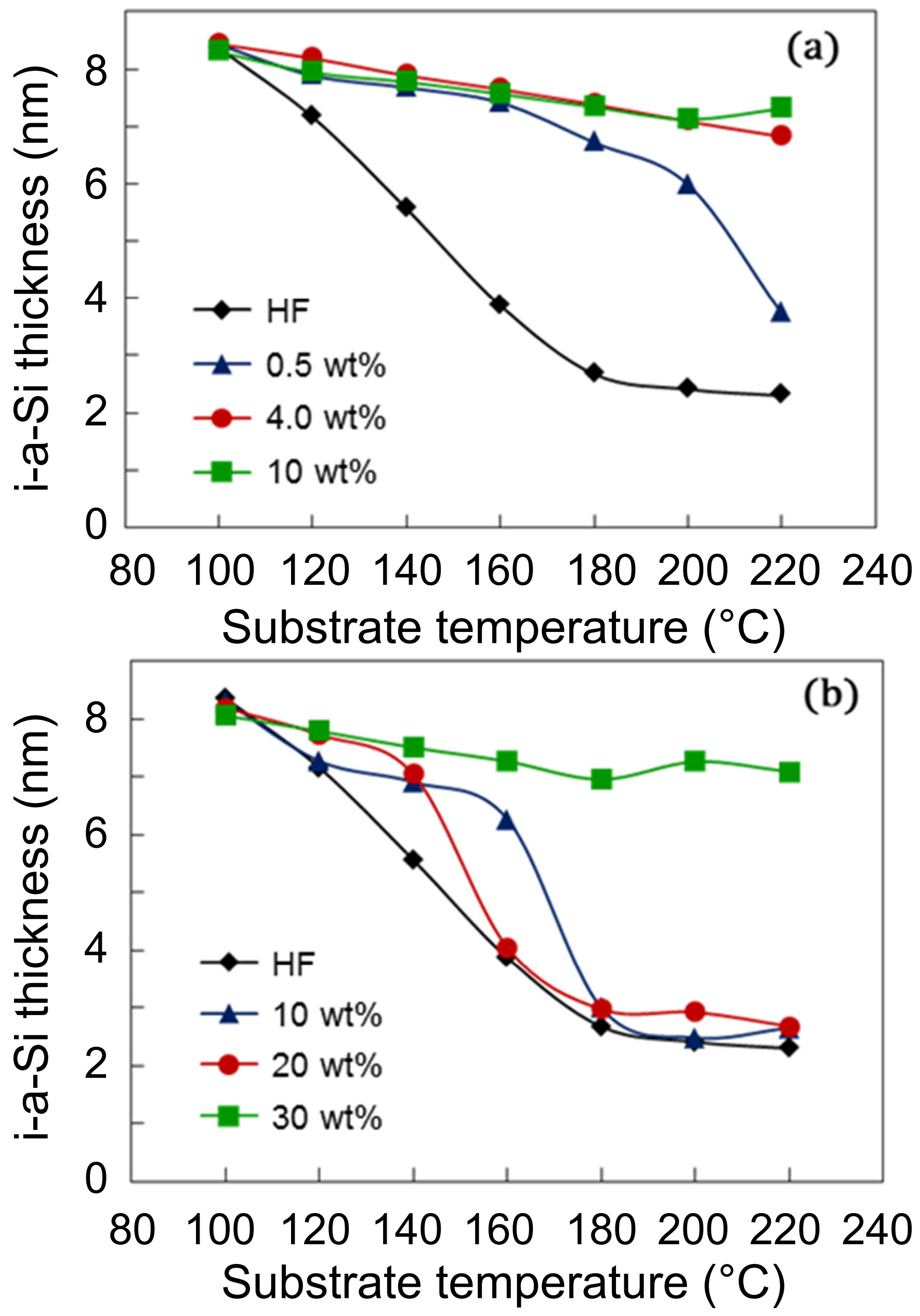


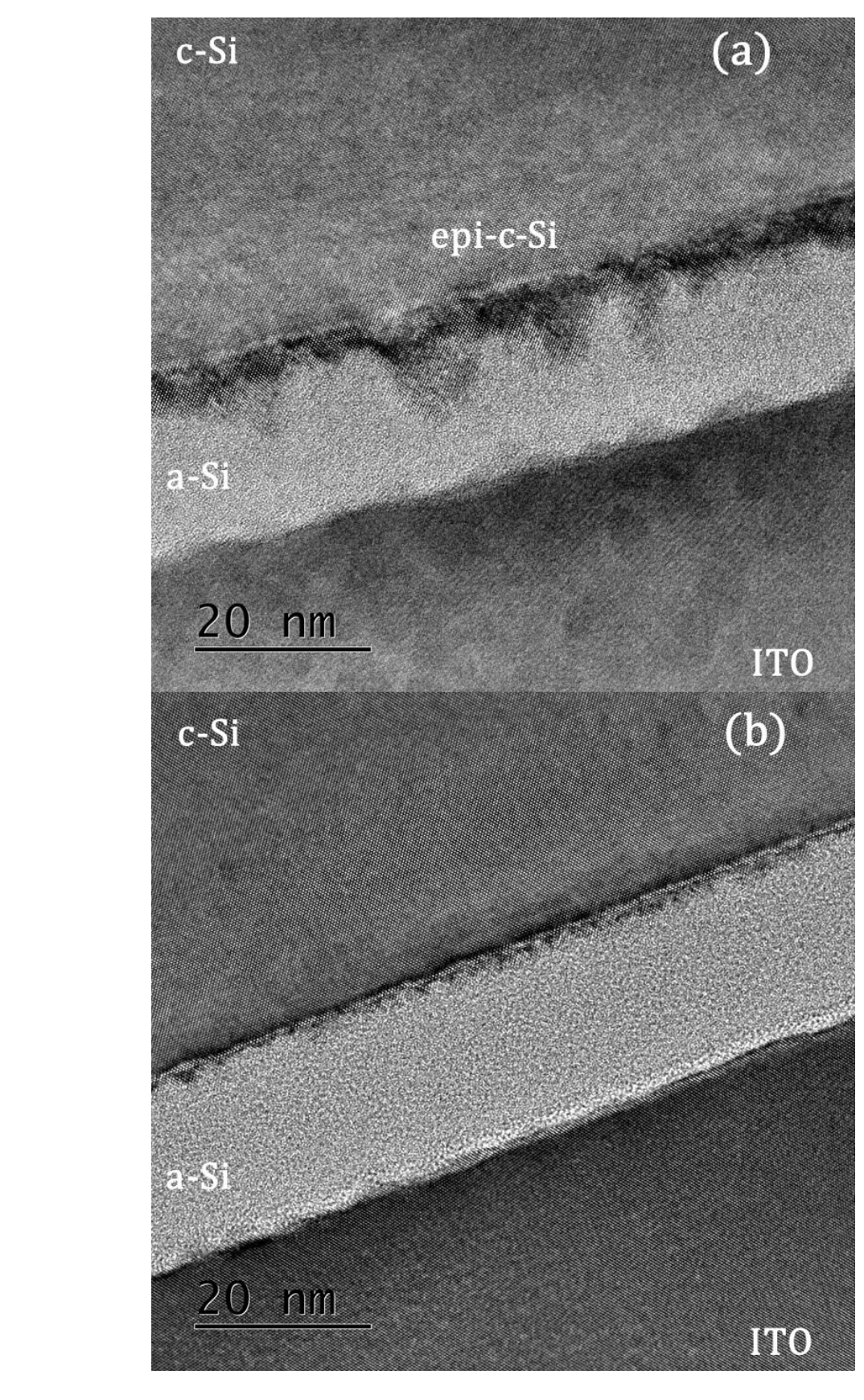

Figure2

Figure2

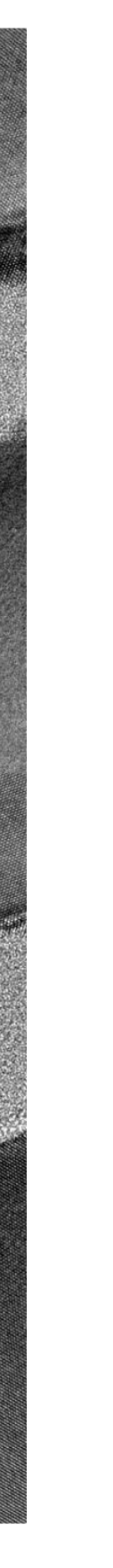
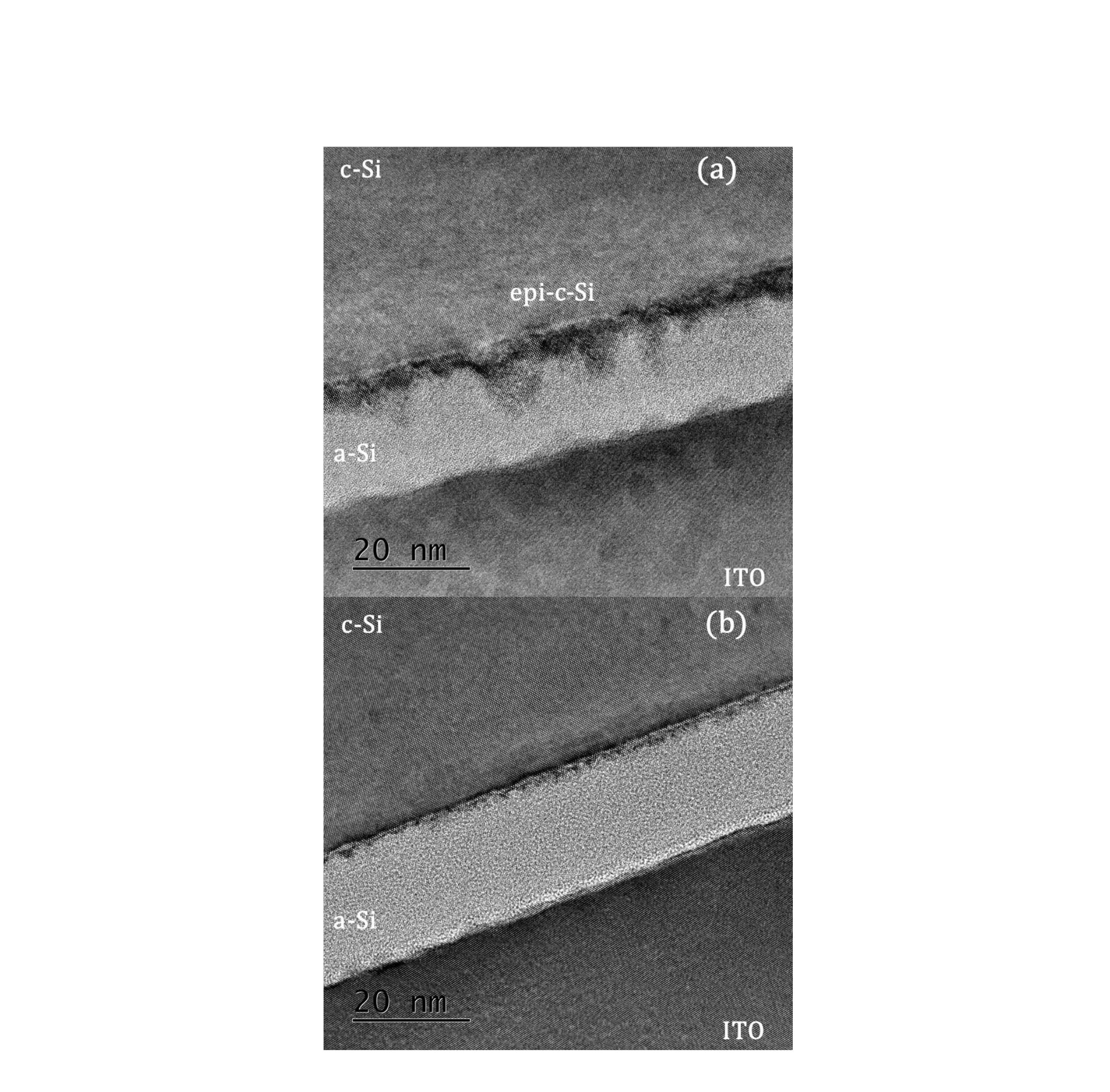


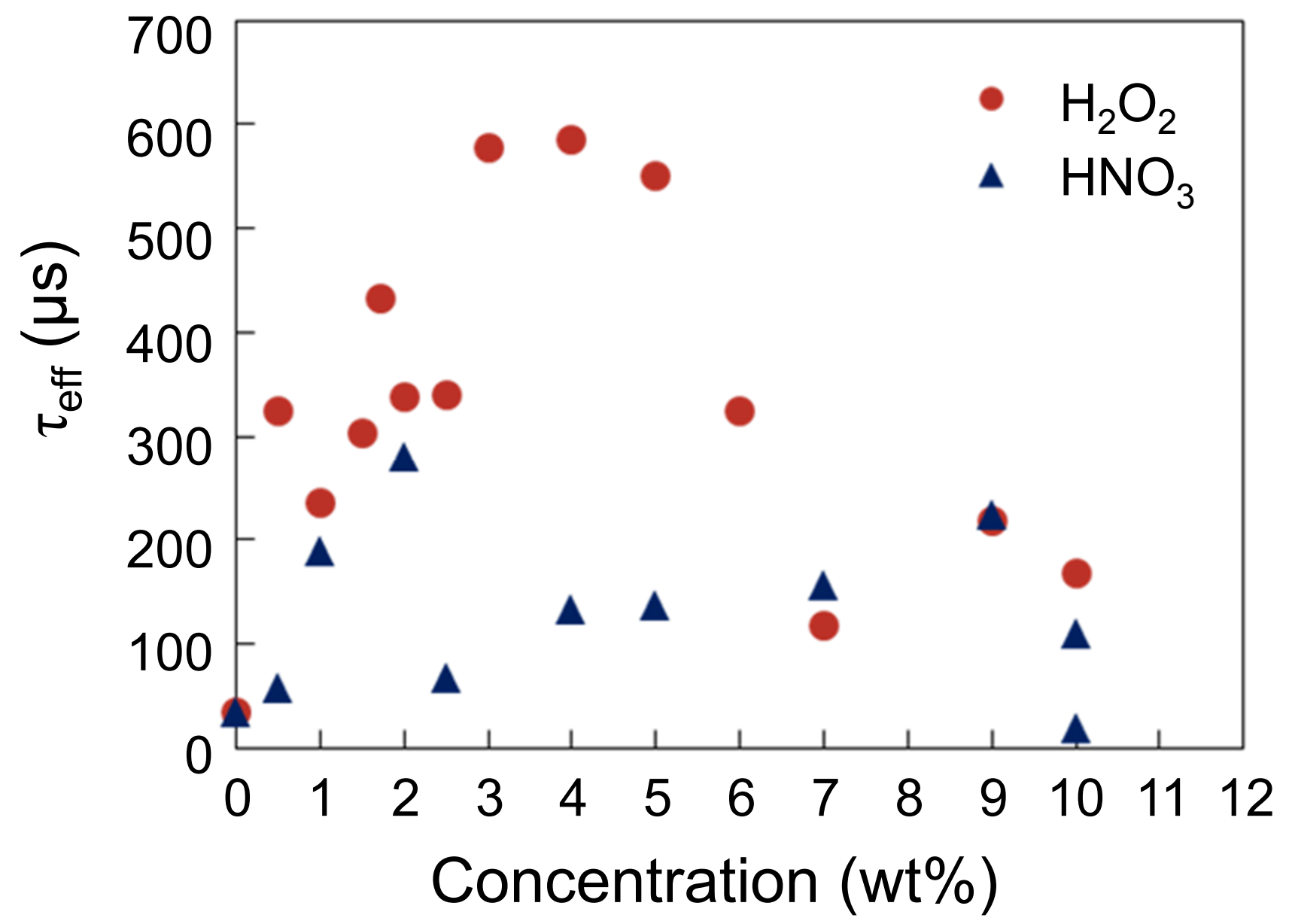



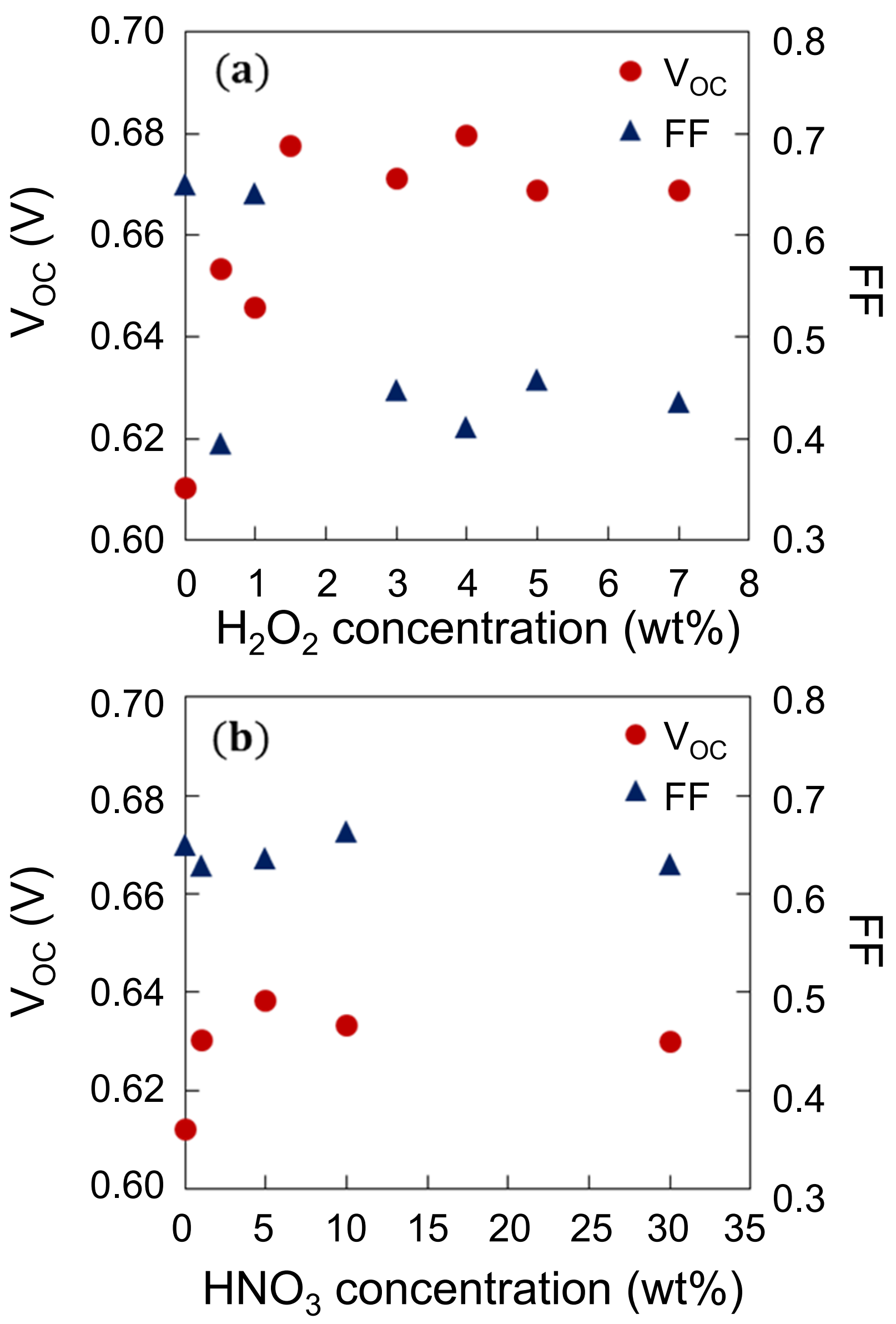


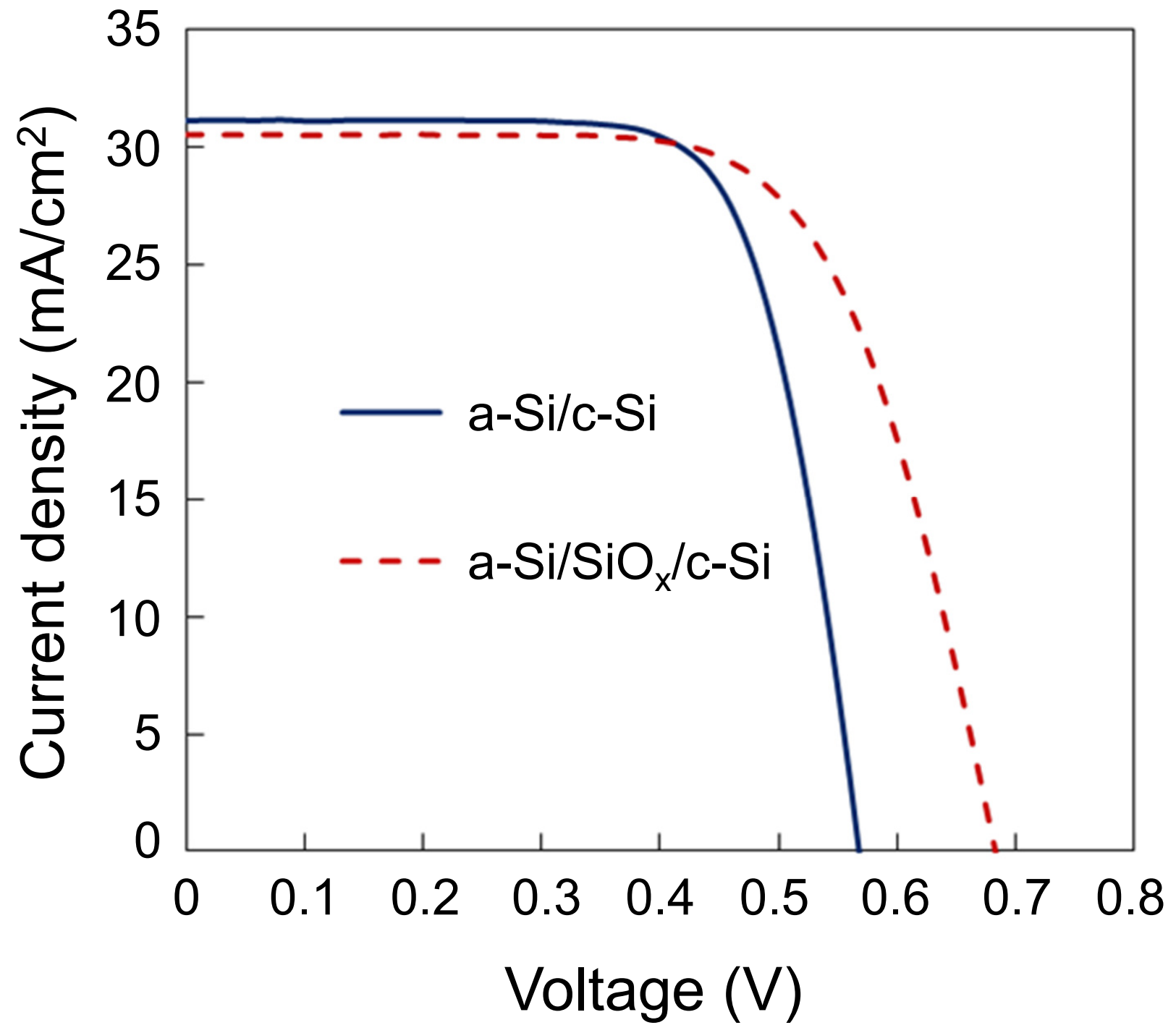



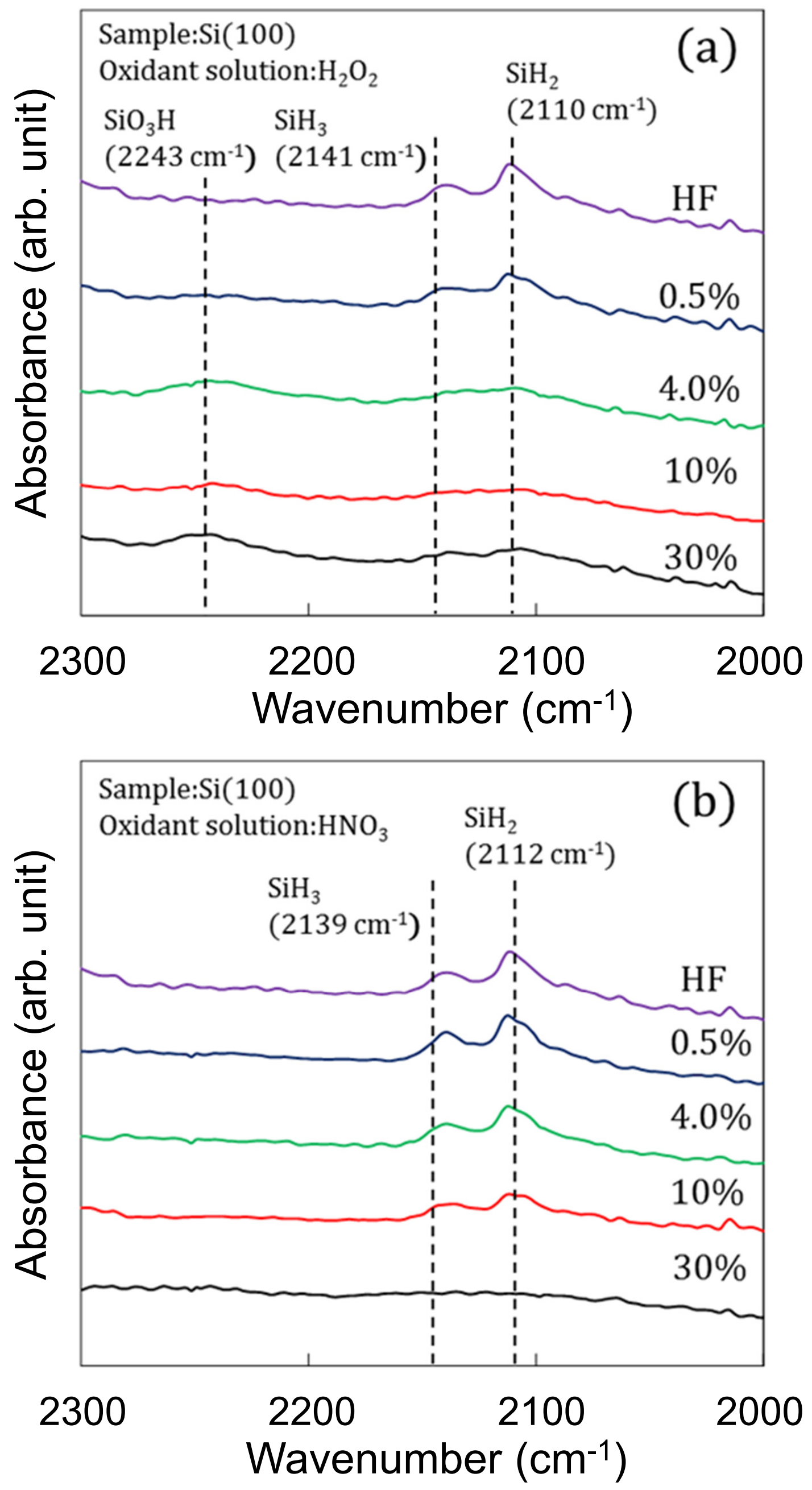
Table I Process conditions for a-Si deposition.

Gas flow rate /sccm

\begin{tabular}{ccccccc} 
& $\mathrm{T}_{\mathrm{s}} /{ }^{\circ} \mathrm{C}$ & $\mathrm{SiH}_{4}$ & $\mathrm{H}_{2}$ & $\mathrm{PH}_{3}$ & $\mathrm{~B}_{2} \mathrm{H}_{6}$ & $\mathrm{P}_{\text {gas }} / \mathrm{Pa}$ \\
\hline i-a-Si & 160 & 10 & - & - & - & 1 \\
n-a-Si & 250 & $20(10)$ & $50(-)$ & 4.4 & - & 2 \\
p-a-Si & 250 & 10 & 50 & - & $8(16)$ & 2 \\
\hline \hline
\end{tabular}


Table II Characteristics of the SHJ solar cells without and with ultra-thin $\mathrm{SiO}_{\mathrm{x}}$ layers on c-Si formed by dipping in $4.0 \mathrm{wt} \% \mathrm{H}_{2} \mathrm{O}_{2}$.

\begin{tabular}{ccc}
\hline \hline & $\mathrm{a}-\mathrm{Si} / \mathrm{c}-\mathrm{Si} / \mathrm{a}-\mathrm{Si}$ & $\mathrm{a}-\mathrm{Si} / \mathrm{SiO}_{\mathrm{x}} / \mathrm{c}-\mathrm{Si} / \mathrm{SiO}_{\mathrm{x}} / \mathrm{a}-\mathrm{Si}$ \\
\hline$\tau_{\text {eff }}(\mu \mathrm{s})$ & 72.6 & 1480 \\
$\mathrm{Imp} . \mathrm{V}_{\mathrm{OC}}(\mathrm{V})$ & 0.591 & 0.714 \\
$\mathrm{~J}_{\mathrm{sc}}\left(\mathrm{mA} / \mathrm{cm}^{2}\right)$ & 31.1 & 30.5 \\
$\mathrm{Cell} \mathrm{V}_{\mathrm{OC}}(\mathrm{V})$ & 0.568 & 0.683 \\
$\mathrm{FF}$ & 0.723 & 0.668 \\
Efficiency $(\%)$ & 12.8 & 13.9 \\
\hline \hline
\end{tabular}

